\title{
The Most Effective Malaysian Legume Plants as Biofacade for Building Wall Application
}

\author{
Atikah Fukaihah Amir (Corresponding author) \\ School of Housing, Building and Planning, Universiti Sains Malaysia \\ 11800 Penang, Malaysia \\ Tel: 60-19-440-6580_E-mail: idealism_85@yahoo.co.uk \\ Foong Swee Yeok \\ School of Biological Sciences, Universiti Sains Malaysia \\ 11800 Penang, Malaysia \\ Tel: 60-12-552-9694 E-mail: foong_sy@yahoo.com \\ Aldrin Abdullah \\ School of Housing, Building and Planning, Universiti Sains Malaysia \\ 11800 Penang, Malaysia \\ Tel: 60-12-410-4715 E-mail: aldrin@usm.my \\ Abdul Malek Abdul Rahman \\ School of Housing, Building and Planning, Universiti Sains Malaysia \\ 11800 Penang, Malaysia \\ Tel: 60-19-448-0205 E-mail: malik@usm.my
}

The research is financed by Universiti Sains Malaysia. No. 1001/PPBGN/843053

\begin{abstract}
Researches on biofacade were mainly on project development. Usually plants selections were based on aesthetics, especially plants with flowers or with canopies. However, very little research has been carried out on the practicality of plants on walls. Basically legume plants produce fruits and can be an asset to the building, without sacrificing its aesthetic value. Four species of legume plants in Malaysia were identified and installed as a biofacade wall. An experiment is being undertaken for all the four species on a building wall to investigate growth performance.
\end{abstract}

Keywords: Biofacade, Legume plant, Growth performance

\section{Introduction}

The term biofacade was used by Sunakorn (2008) as "a combination between natural environment and build environment forming a biological building skin". There are lots of similar phrases or keywords that have been used in many researches namely, the vertical garden (Blanc, 2008), green facades (Kohler, 2009), bioshader (Ip, 2009), living wall (Dunnet, 2008), green wall (Irwin, 2009) and Vertical Greenery System (VGS) (Wong, 2009).

A legume plant is a horticultural term for plant that produces pods of pea or bean. The main purpose in choosing a legume as biofacade wall is to investigate the viability of wall surfaces as an alternative space for producing food for human needs in urban areas where land for agriculture is gradually getting scarce. World population is increasing giving rise to the demand of food supply.

It has been reported (Xiong, 2007) that the agricultural sector can cause high impact on climate change and food insecurity. According to Groot (1998), the condition in which all people at all times have access to the food they need for a healthy and active life is defined as food security.

One way is to grow legume plants as an alternative way to provide security. Newman (1992) stated how people were "forced" at the beginning because of the increased scarcity of wild resources and started to realize that it was productive and useful to grow their own plants. This is supported by Cakmak (2002) in his statement that the food production on presently used land must be doubled in order to meet the food demand of a growing world population in the next two decades. Since land is getting expensive especially in urban setting, space required for agricultural crops is less. In addition, according to Lotze-Campen (2006), about 50\% more people have to be fed than was predicted to fulfil the food demand. Basically, people in town (urban) are used to 
importing food from rural agriculture. Urban lands are expensive thus planting an agriculture crop would not be cost-effective.

Ramankutty (2008) analysed the statement made by Lal in the year of 1989, which states that in the twentieth century, the global distribution of croplands changed when cropland base diminished from approximately 0.75 ha/person in 1900 to approximately 0.35 ha/person in 1990. It was estimated that a minimum cropland area of $0.5 \mathrm{ha} /$ person is required to provide an adequate diet. There are issues concerning food self-sufficiency.

Loh (2008) stated that approximately RM1.4 billion was spent to import vegetables into Malaysia which has a population of 27 million. He also pointed out that despite having the highest biomass production in the world Malaysia is not self-sufficient in food production. The reason for this is the low level of technology currently in use. In addition, Newman (1992) mentioned that this may be due to the centralization of population density in one place like urban settings which require more attention to food production at any one time. In summary, food plants can be planted in urban areas within a minimal space like the biofaçade. This approach not only reduces the percentage of import from overseas, but can generate profit by exporting surplus food crop from the biofaçade. Lots of design factors have been discovered which are not yet popular for construction development in Malaysia.

\section{The benefits of biofacade}

Most of the published work on this topic originates from German studies (Kohler, 2009). Biofacade can give various benefits to human life such as visual screening and improved aesthetics. According to Kohler (2009), less than $5 \%$ of all facades in Berlin were grown with plants on the external building wall. In Singapore, Wong (2009) currently experimented on various vertical greenery systems for comparison on which system can reduce wall temperature.

Fruits from green facades such as espaliers systems are edible (Kohler, 2009). Espaliers have been used for hundreds of years. According to Taraba (2008), approximately as early as the year 1850, grapevine was planted on building wall in Central Europe with a very specific purpose which was for wine production. Since grape is a fruit that is often used daily, the popularity to grow has increased.

The issue with fruit planting on walls is that it has to be maintained constantly. Regular care and trimming are needed to prevent damages on external wall. According to Dunnet (2008), irrigation was one of the concerns in climates which experience seasonal drought. For tropical climates such as Malaysia, roots of large climbers usually grow in the cool shade of the forest. Therefore, problems of high temperature and reduction in soil moisture at the foot of buildings are common. With particular maintenance, fruit production on walls is capable in reducing food import. In Malaysia, growing fruit plants on wall is not yet popularly applied. However, growing vegetables and herbs using simple staking on agriculture crop are well known and somehow can be applied on walls as well.

Kohler (2009) stated that green facades have value in biomass production. They can produce fruit weighing up to 23 tons/ha/year. According to Hassan (2006), Malaysia can be categorized as a place that has the highest biomass production because of its high sunlight intensity and rainfall. Malaysia has the potential for biomass production with biofacade development. For example, Simsek (2008) stated that other than as food, Pisum sativum or sweet pea can be made into biodegradable thermoplastics. Plastic can be categorized into two which are thermoplastics and thermosetting polymers. Thermoplastics can be remoulded and reshape, different with thermosetting polymers which cannot reshape. According to American Chemistry Council (2010), raw material like natural gas and petroleum usually will take part when plastics were made. For example polystyrene container which is widely used. Another example for a renewable biomass sources are the pea starch, an alternative to fossil fuel plastics which were derived from petroleum. This alternative will keep plastic to be sustainable.

The potential for energy production from crop residues might be an option for recycle management. According to Jigura (2008), all biomass can be turned into energy with the help of wide technologies. For example, Jigura (2008) stated that crop residues from maize, sorghum, wheat, groundnuts, soybeans, cotton, sugarcane, tea, sunflower and fruit were transformed into energy and were widely used in Zimbabwe from 1984 to 1999.

In addition, the layer of leaves which is planted on walls also serves as dust and particulate reduction traps especially in urban spaces. Research in German by Kohler (2009) shows, leaves could trap the dust and it was estimated that up until $4 \%$ of the annual dust-fall could be trapped if all the buildings' potential facade in an inner city neighbourhood were greened. According to $\mathrm{Li}$ (2008), another benefit of vegetated walls is the air purifying effect and for the thermal conductance for buildings. According to Wong (2009), an experimental study in Singapore, the wall temperature can be reduced to $4-12^{\circ} \mathrm{C}$ depending on the leaves foliage and the type of planting system.

Moreover, Blanc (2008) stated plant leaves are fertilized, decomposed and mineralized by polluting particles from the air. Although in Malaysia, with its frequent rainfall, the possibilities of wall to get smeared from dust trapped on leaves might be a factor of concern. 
Biofacade can assist carbon neutrality which affects global warming. Plants absorb carbon dioxide but the exact amount of each plant's uptake has yet to be discovered. On plant selection for the biofaçade wall, it is critical to pick the plants which have the potential for a high carbon dioxide uptake. For example, plants for the biofacade have to possess good heat tolerance. According to Wahid (2007), plant which are able to grow and produce economic yield under high temperatures were defined as plant that has heat tolerance. In the mean time, plants chosen have to be good when exposed to the sun or categorized as hardy plants.

Darker leaves have the potential for higher rating of carbon absorption. Dark green leaves or dark pigments absorb more radiant energy used in photosynthesis. Subsequently, biofacade also can act as a surface shelter or thermal insulation for energy savings to building. It means, biofaçade is believed capable of mitigating the urban heat island effect especially in urban areas. Blanc (2008) stated, energy consumption can be lowered by use of vertical garden.

Biofaçade can reduce the intensity of noise or act as a natural barrier. Li (2008), quoted from Prof. Wong Nyuk Hien, in one of the Singapore projects on green façade, the Newton Suite Apartment had its inside noise level measured and shows a reduction up to 10 decibels compared to walls without plants .

Moreover, biofaçade is a valuable wildlife habitat. Blanc (2008) strengthens the statement with many projects in vertical garden that allows man to recreate a living system very similar to natural environments. Looking at the plant element, legumes and flowers of the plant basically act as attraction to animal kingdom especially the small creature. For example, birds are attracted to legume. Same goes to the butterflies and bees which are attracted to the nectar produced by the flowers.

Furthermore, biofaçade is easy to build. Clients have another alternative to go green with low cost construction. According to Kohler (2009), construction costs on green facades for building wall are low compared to the green roof project. Green roof require special roof construction and have to consider the additional insulation, whereas green façade only require trellis or cable to be attached on the building.

However, $\mathrm{Li}(2008)$ stated that the popularity of green wall is stemmed by the cost of its maintenance. Average photosynthesis in tropical climate is much higher than temperate climate (hibernation period in winter). Kikuzawa (1999) summarizes report on Williams in 1989, gave the example of Piper sp., that leaf longevity of tropical shrubs was correlated with photosynthesis rate and construction cost. Kikuzawa (1999) then experimented the comparison on both tropical and temperate plants, strengthening too on the equation that leaf life span is short when photosynthetic assimilation rate of the leaf is high, and so the construction cost (production of leaves) is low. This applies to most of plant species for both climate. Therefore, the maintenance cost on the plants on biofaçade in Malaysia climate might be higher; because of the need to replant consequently of leaf longevity is low.

\section{The objective of biofacade}

\subsection{Vegetable and herb plants to solve food and medicinal import problems}

Vegetables and herb plants are of food and medicinal importance in our daily lives. The population of human increases every year and food supply is needed to parallel with human population growth. Loh (2008) stated 70.4\% were imports on food. The Secretary for the Federation of Malaysian Growers Association (PPSM), said that Malaysia produces 700,000 metric tonnes of vegetables every year of which 170,000 tonnes were exported to Singapore. 500,000 tonnes of vegetables were imported back to cover Malaysia's needs. However, to prevent global warming, we must also be concern about the consequences of importing such as, the cost of transportation, packaging and chemicals to the vegetables. So, the solution to plant these vegetables locally is an alternative. If prices of land are to be a concern, biofacade can be at the household level or even in the office blocks. Table 1 shows the highest possibilities of the climbing plant resistant to the Malaysian climate, durable, absorbs well on carbon dioxide and can provide food on long term. Furthermore, apart from harvesting the fruits for food only, we can also use the flowers, leaves, young shoot and tubers as well as medicinal contribution.

\subsection{Vegetables and herb plants for $\mathrm{CO}_{2}$ uptake}

Plant act as intermediate to assists carbon neutrality in atmosphere. An experiment made by Sunakorn (2006) explored vertical plantings on levelled parking structures due to shortage of space. He demonstrated that they could provide more surface area to absorb carbon dioxide especially in urban areas. Urban spaces are more heated compared to the rural areas due to the many exposures from carbon from power plants, cars and buildings. Lemon (1983) quoted from Gates, mentioned that oil, gas, and coal are estimated to contain nearly $4,130 \times 10^{9}$ metric tons of carbon of world's remaining recoverable resources. He added that the atmospheric carbon dioxide concentration would be increased by a factor of four if the total oil, gas, and coal were burned and half remains airborne. So, renewable energy that is the provision of energy from clean resources (solar power, wind power, biomass, hydro etc) would gradually replace the fossil fuel resources but there are no initiatives to absorb the saturated carbon dioxide in the atmosphere that is causing the global warming.

According to Lemon (1983), on an average in a laboratory experiment, plant growth increases about $0.9 \%$ when $0.1 \%$ of carbon dioxide concentrations were increased. So, there is a probability for plants to grow faster in 
urban spaces where the carbon dioxide can act as plant fertilizer. Lemon (1983) experimented to trace the cumulative effects of carbon dioxide on yield and plant growth. Two plants were compared and observed, one grown in a "normal" atmosphere and the other one grown in a "high" carbon dioxide atmosphere. "Normal" means estimated $340 \mathrm{ppm}$ carbon dioxide, and "high" might be, for example, $600 \mathrm{ppm}$ of carbon dioxide. From the experiments, there was evidence that some small seeds placed on the soil surface germinate faster in high carbon dioxide settings. Once the shoot has emerged, it responds to high carbon dioxide by initiating and expanding each leaf faster, achieving a larger leaf area. However, this effect is not seen in all species.

In another experiment made by Lemon (1983), there was no effect on the leaf protein content on a leaf weight basis on Nerium oleander plants at $660 \mathrm{ppm}$ as compared with $330 \mathrm{ppm}$ carbon dioxide. However, it only caused a significant increased on a leaf area basis. As for Atriplex triangularis, lower leaf protein contents were found at $660 \mathrm{ppm}$ compared to $330 \mathrm{ppm}$ carbon dioxide concentration on both leaf weight and leaf area basis. In summary, carbon dioxide concentration as plant fertilizer can be varied on different kinds of plants. From the observation of various plants in Malaysia, leaves which have a darker green surface can be summarized as those that take higher carbon uptake rather than light green or purplish leaves. In the plant selection, the criteria to have a broader leaves surface and darker green leaves were chosen such as Vigna unguiculata sesquipedalis.

\subsection{Vegetable and herb plants to reduce indoor temperature}

Each time people enter the building, we switch on the air conditioner to cool down the room. However, according to Priyadarsini (2009), waste heat was dumped into the atmosphere although air conditioner can improve the indoor thermal environment of a building. It just made the urban thermal environment worse. However, using biofacade as external shading devices is one of the alternatives for saving building energy. A plant is mainly known to can give shade and cool the space, especially those with broad leaves.

The concept of biofacade is simple. Biofacade act to cool down the outside temperature by planting on building wall faces both morning and afternoon sun orientation. It is practically can be applied in urban spaces which the prices of land are higher. Furthermore, biofacade can reduce urban heat island effects especially in daytime by evapotranspiration made by leaves and soil. According to Priyadarsini (2009), it creates the environment cooler than their surrounding and so was termed "oases".

This has been demonstrated by various studies to monitor the room conditions. For example, Ip (2009) stated that Virginia creeper planted on building wall at University of Brighton, United Kingdom recorded on the reduction of temperature $4-6{ }^{\circ} \mathrm{C}$ on the peak summer was achieved. Parallel with the study of Laopanitchakul (2008) in Thammasat University, Bangkok, one of the comparisons made for two different models such as bare building wall and building wall with climbing plant. The result showed that during periods of maximum air temperature, walls with climbing plants performed better in reducing heat transfer compared to bare walls by as much as $7.03{ }^{\circ} \mathrm{C}$. At night, the temperature for both the bare wall and the planted walls are about the same at 26 ${ }^{\circ} \mathrm{C}$. In conclusion, wall with climbing plant perform better in heat transfer reduction especially during the day.

\section{Plants identification}

\subsection{Pisum sativum (Sweet pea)}

According to Herklots (1972), garden pea is native to or originated from South-West Asia. Garden peas are mainly grown for its pea, compared to winged bean which has multi-purpose use. However, The World's Healthiest Food (2010), stated that only about $5 \%$ of the peas grown are sold fresh. The rest are either frozen or canned. Frozen peas are preferable to canned peas as they retain their flavour and have lower sodium content. Through research, pea can be made into bio-plastics or organic plastics products. The largest commercial producers of fresh peas are the United States, Great Britain, China, Hungary and India. Many cultivars reach maturity about 60 days after planting. (Figure 1)

\subsection{Vigna unguiculata sesquipedalis (Long bean)}

According to Singh (1985), Vigna unguiculata sesquipedalis is ancient in Africa and Asia. According to Herklots (1972), it has three-lobed leaves and long narrow pods and it was an annual with variable habit and reaches the maturity in 60 days after sowing, hang in pairs. It can be harvested every two days afterwards. However, Singh (1985) stated the maturity of cultivars is in 90 days and pods were produce in 50 days, or late cultivars could take 240 days to mature. They were best if picked for use a vegetable before they reach full maturity. He also stated that yard long bean was categorized in subtropical or tropical and most widely grown in the warmer parts of South-eastern Asia, Thailand, and Southern China. (Figure 2)

Singh (1985) added that it is widespread in Africa and spreading by way of Egypt or Arabia to Asia and Mediterranean. Usually, pods were the main reason for its cultivation. The flowers usually open early in the morning and closes by noon. The flowers will fall off on the same day. According to Singh (1985), Vigna unguiculata sesquipedalis can be grown with less rainfall and under more adverse conditions than Phaseolus vulgaris. It can be grown with moderate amount of shade. Seeds germination should be planted in non-humid season to ensure the stabilized growth. He added that Vigna unguiculata sesquipedalis is almost entirely self-pollinated by ants, flies and bees as the main vectors. 


\subsection{Psophocarpus tetrogonobulus (Winged bean)}

Winged bean is one of the most commonly cultivated leguminous crops in Malaysia. Jalani (1978) stated, it is frequently found around the houses especially in the villages as well as in the big cities. However, according to Isa (2007), with the new technologies in agriculture, vegetables starts to have commercial value since Malaysia began taking in demand from all over the country. Amongst the benefits of winged bean in human consumption for young parts which is young pods, leaves, shoots and flowers are being used as vegetable. Jalani (1978) stated in Malaysia, winged bean were either eaten raw as salad or cooked with additional spices. He added that winged bean among young or green pods have a "pungent" odour, which discourage people from eating them. For mature seeds, it was consumed either parched or fried. The flowers are also used in food colouring such as local cakes but it is rarely made. Herklots (1972) and Jalani (1978) added that tubers of winged bean consumed either boiled or fried and can be eating afterwards. However, very few people knew that winged bean were produces tuber which can be consumed. (Figure 3)

Winged bean is known to have medical use. Jalani (1978) stated that swelling and pain caused by insects' bites and stings can be reduced by use of winged bean. The young leaves are usually rolled or meshed with betel leaves. He also states that winged bean can help cure impotency using mixtures of mature seeds and other ingredients. Meshed young leaves, shoots and flower buds can be used as a stimulant for hair growth. The tubers either dried or fresh are boiled in water and the latter especially beneficial for women after giving birth.

\subsection{Phaseolus vulgaris (Kidney bean)}

Singh (1985) stated kidney beans are categorized as a highly nutritious crop and as a low-cost protein food. The crop harvests are also useful to feed livestock such as cattle, goat and horses. (Figure 4)

According to Herklots (1972), kidney bean originates from Peru. Subsequently, Spanish and Portuguese traders introduced kidney beans into Africa and Asia. Amongst the benefits of winged bean in human consumption was very good source of cholesterol-lowering fibre. Furthermore, kidney bean also good for diabetes, insulin resistance or hypoglycaemia. Jamaluddin (1997) added that kidney bean was grown for its pods. Furthermore, he stated that it has vitamin A, twice more than yard-long bean. Herklots (1972) observed that from 40-60 days seed growth, young pods may be picked for harvesting period. Every three days afterwards, kidney bean can be harvested. According to Singh (1985), kidney bean is very useful to treat various illness or disease such as for acne, diabetes, burns, diarrhea, dropsy, dysentery, eczema, hiccups, itch, rheumatism, sciatica, and tenesmus.

\section{Conclusions}

Multi-purpose use of plants, such as carbon neutrality factor in urban areas or as shading devices among others, are becoming a key design consideration in modern built environment. The technique on the installation of the biofacade should be easily movable externally such as using wire rope where maintenance on wall could be easier after years of vertical planting on wall. Malaysia is a hot-humid country and this means that the maintenance of wall and plant would be higher. When this research is carried out by applying biofacade to an actual full-scale building wall, we will get a better idea about the practical implementation and real energy savings and hopefully some lessons can be learnt for practical application for Malaysian building walls.

\section{Acknowledgment}

Acknowledgement is made for Associate Prof. Dr. Abdul Malek Abdul Rahman for his assistance in idea contribution as well as helping in proof reading. Special regards to Dr. Foong Swee Yeok and Kumaradevan a/l Samir from the School of Biological Sciences for the guidance in plant selection as well as the School of Housing, Building and Planning, Universiti Sains Malaysia for the research funding.

\section{References}

\section{Reference to a journal publication:}

Cakmak, I. (2002). Plant nutrition research: Priorities to meet human needs for food in sustainable ways. Plant and soil, 247, 3-24.

Groot, J. J. R., Vries, F. W. T. P. d., \& Uithol, P. W. J. (1998). Food supply capacity study at global scale. Nutrient Cycling in Agroecosystems, 50, 181-189.

Ip, K., Lam, M., \& Miller, A. (2009). Shading performance of a vertical deciduous climbing plant canopy. Building and Environment, (In Press) 1-8.

Jingura, R. M., \& R.Matengaifa. (2008). The potential for energy production from crop residues in Zimbabwe Biomass and Bioenergy, 32, 1287-1292.

Kikuzawa, K., \& Ackerly, D. (1999). Significance of leaf longevity in plants. Plant Species Biology, 14, 39-45.

Köhler, M. (2008). Green facades - a view back and some visions. Urban Ecosyst, 11, 423-436.

Laopanitchakul, V., Sunakorn, P., \& Srisutapan, A. (2008). Climbing-Plant on solid wall for Reducing Energy in Tropical Climate Paper presented at the Sustainable Building Conference 2008 Seoul, Korea. 
Priyadarsini, R. (2009). Urban Heat Island and its Impact on Building Energy Consumption. Earthscan, 3, 261-270.

Simsek, S., Tulbek, M. C., Yao, Y., \& Schatz, B. (2008). Starch characteristics of dry peas (Pisum sativum L.) grown in the USA. Food chemistry, 115, 832-838.

Sunakorn, P., Pakarnseree, R., \& Davivongs, M. L. V. (2006). The Application of Plants on Parking Structures to reduce $\mathrm{CO}_{2}$ Paper presented at the iNTA Conference 2006 - Harmony in Culture and Nature

Wahid, A., Gelani, S., Ashraf, M., \& Foolad, M. R. (2007). Heat tolerance in plants: An overview. Environmental and Experimental Botany, 61, 99-223.

Wong, N. H., Chen, Y., Ong, C. L., \& Sia, A. (2002). Investigation of thermal benefits of rooftop garden in the tropical environment. Building and Environment, 38, 261-270.

Wong, N. H., Tan, A. Y. K., Chen, Y., Sekar, K., Tan, P. Y., Chan, D., et al. (2009). Thermal evaluation of vertical greenery systems for building walls. Building and Environment, 45, 663-672.

Xiong, W., Lin, E., Ju, H., \& Xu, Y. (2007). Climate change and critical thresholds in China's food security. Climatic change, 81, 205-221.

Reference to a book:

Beckett, K. A. (1983). Climbing Plants. Portland, Oregon: Croom Helm

Blanc, P. (2008). The Vertical Garden: From Nature to the City. New York: Norton, W. W. \& Company, Inc.

Dunnet, N., \& Kingsbury, N. (2008). Planting Green Roofs and Living Walls. London: Timber Press.

Herklots, G. A. C. (1972). Vegetables in South-East Asia. London: George Allen \& Unwin Ltd.

Jamaluddin. (1997). Terung, labu air, kacang buncis. Kuala Lumpur: Seri Kembangan: Pustaka Budi.

Lemon, E. R. (1983 ). $\mathrm{CO}_{2}$ and Plants: AAAS Selected Symposium.

Newman, L. F. (1992). Hunger in History: Food Shortage, Poverty and Deprivation. Massachusetts: Blackwell Publishers.

Singh, S. R., \& Rachie, K. O. (1985). Cowpea: Research Production and Utilization. Great Britain: John Willey $\&$ Sons.

Reference to a chapter in an edited book:

Jalani, B. S., \& Wong, K. C. (1978). The winged bean - Research Status and Uses of Winged Bean in Malaysia:. In P. C. f. A. a. R. Research (Ed.), International Symposium on Developing the Potentials of the Winged Bean (1st : 1978 : Manila), (Vol. 1, pp. 403-406). Philippines: Philippine Council for Agriculture and Resources Research, Los Banos, Laguna.

Lotze-Campen, H., Müller, C., Bondeau, A., Smith, P., \& Lucht, W. (2006). Rising Food Demand, Climate Change and the Use of and Water. In F. Brouwer \& B. A. McCarl (Eds.), Agriculture and Climate Beyond 2015 (pp. 109-129). Netherlands: Springer

Ramankutty, N., Foley, J. A., \& Olejniczak, N. J. (2008). People on the land: Changes in population and global croplands during the 20th century. In A. K. Braimoh \& P. L. G. Vlek (Eds.), Chapter 3: Land-Use Change and Global Food Production (pp. 23-40): Springer Science.

Reference to a web source:

American Chemistry Council. (2005-2010). Life cycle of a plastic product. [Online] Available: http://www.americanchemistry.com/s_plastics/doc.asp?CID=1571\&DID=5972 (Nov 26, 2010)

Hassan, M. A., Yacob, S., \& Ghani, B. A. (2006). Utilization of Biomass in Malaysia. Potential for CDM Business. [Online] Available: www.jie.or.jp/pdf/16.Prof.Hassan.pdf (Oct 1, 2010)

Irwin, G., (2009), Green Wall Research, Full Steam Ahead! [Online] Available: www.greenroofs.com (Oct 1, 2010)

Isa, Z. (2007). Sayur Ulam: Dunia Pemakanan Sihat. [Online] Available: http://www.yadim.com.my/Kesihatan/KesihatanFull.asp?Id=165 (Oct 1, 2010)

$\mathrm{Li}$ T. C. (2009). Upright gardens [Online] Available: http://thestar.com.my/lifestyle/story.asp?file $=/ 2009 / 8 / 4 /$ lifefocus/4319613\&sec=lifefocus (Sept 28, 2010)

Loh, J., \& Bedi, R. S. (2008). Yet to grow our own food. [Online] Available: http://thestar.com.my/news/story.asp?file=/2008/5/11/focus/21193194\&sec=focus (Sept 28 2010)

Stephens, J. M. (2003). Bean, Yard-Long - Vigna unguiculata subsp. sesquipedalis (L.) Verde. [Online] Available: http://edis.ifas.ufl.edu/pdffiles/MV/MV02900.pdf ( Sept 28, 2010)

Sunakorn, P. (2008). Biofacade. from Kasetsart University Research and Development Institute. [Online] Available: http://biofacade.com/Eng001_Home.html (Nov 11, 2010) 
Taraba, S. (2008). The History of Facade Greening. [Online] Available: http://www.fassadengruen.de/eng/indexeng.htm (Oct 1, 2010)

The World's Healthiest Foods. (2001-2010). Green Peas. [Online] Available. http://whfoods.org/genpage.php? tname $=$ foodspice\&dbid $=55$ (Nov 11, 2010)

Wikipedia The Free Encyclopedia. (2010). Common bean. [Online] Available: http://en.wikipedia.org/wiki/Common_bean (Nov 11, 2010)

Table 1. Plant selection (Table modified from Ip, 2003)

\begin{tabular}{|c|c|c|c|c|c|}
\hline $\begin{array}{c}\text { Species/ Local } \\
\text { name }\end{array}$ & $\begin{array}{c}\text { Sun \& } \\
\text { water } \\
\text { tolerance }\end{array}$ & $\begin{array}{c}\text { Climbing } \\
\text { method }\end{array}$ & Height & Leaf/ flower & Soil type \\
\hline $\begin{array}{l}\text { Psophocarpus } \\
\text { tetragonolobus } \\
\text { (Winged bean) }\end{array}$ & $\begin{array}{l}\text { Full sun. } \\
\text { Lots of } \\
\text { water }\end{array}$ & Tendril & $9-12^{\prime}$ & $\begin{array}{l}\text { The pods (legume) are } \\
6-9 \text { " long and 1"broad. } \\
\text { Leaf 3-6" long. Blue } \\
\text { flower colour. }\end{array}$ & $\begin{array}{l}\text { Does well in a variety } \\
\text { of soils except sands or } \\
\text { high salinity } \\
\text { environments. } \\
\text { Soil pH: } 4.3-8.5 \\
\text { Reference: } \\
\text { (Jalani, 1978) } \\
\text { (Herklots,1972) }\end{array}$ \\
\hline $\begin{array}{l}\text { Phaseolus } \\
\text { vulgaris } \\
\text { (Kidney bean) }\end{array}$ & $\begin{array}{c}\text { Full sun. } \\
\text { Moderate } \\
\text { water }\end{array}$ & Twining & 6-10' & $\begin{array}{l}\text { The pods are } 8-20 \mathrm{~cm} \\
\text { long, } 1-1.5 \mathrm{~cm} \text { wide. } \\
\text { Leaf } 6-15 \mathrm{~cm} \text { long } \\
\text { and } 3-11 \mathrm{~cm} \text { wide. } \\
\text { Flower white, pink, or } \\
\text { purplish. }\end{array}$ & $\begin{array}{l}\text { Well-drained, sandy } \\
\text { loam, silt loam or clay } \\
\text { loam soils, rich in } \\
\text { organic content. } \\
\text { Soil pH: 4.0-9.0 } \\
\text { Reference: } \\
\text { (Herklots,1972) } \\
\text { (Jamaluddin, 1997) } \\
\text { (Singh, 1990) }\end{array}$ \\
\hline $\begin{array}{l}\text { Vigna } \\
\text { unguiculata } \\
\text { sesquipedalis } \\
\text { (Yard long } \\
\text { bean) }\end{array}$ & $\begin{array}{c}\text { Full sun. } \\
\text { Moderate } \\
\text { water }\end{array}$ & Twining & $9-12^{\prime}$ & $\begin{array}{l}\text { The pods that are } \\
\text { typically } 51 \mathrm{~cm} \text { long. } \\
\text { Leaves are trifoliate, } \\
\text { green, oval and } \\
\text { smooth-edged. White, } \\
\text { yellow and purple } \\
\text { flower colour. }\end{array}$ & $\begin{array}{l}\text { Grows well in poor } \\
\text { soils with more than } \\
85 \% \text { sand and with less } \\
\text { than } 0.2 \% \text { organic } \\
\text { matter and low levels of } \\
\text { phosphorus. } \\
\text { Soil pH: } 4.3-7.5 \\
\text { Reference: } \\
\text { (Stephens, } 2003 \text { ) } \\
\text { (Herklots, } 1972 \text { ) }\end{array}$ \\
\hline $\begin{array}{l}\text { Pisum sativum } \\
\text { (Garden pea) }\end{array}$ & $\begin{array}{l}\text { Full sun. } \\
\text { Moderate } \\
\text { water }\end{array}$ & Tendril & $3-6$ & $\begin{array}{l}\text { The pod to 5" long. } \\
\text { Leaflets broad and } \\
\text { ovate with distinct } \\
\text { ribs, and slightly } \\
\text { toothed or entire. } \\
\text { Flower colour differs } \\
\text { according to cultivar } \\
\text { with white, pink, } \\
\text { lavender, blue and } \\
\text { purple represented. }\end{array}$ & $\begin{array}{l}\text { Slightly acidic, } \\
\text { well-drained soils. } \\
\text { Soil pH: } 6.0-7.0 \\
\text { Reference: } \\
\text { (Beckett, 1983) } \\
\text { (Herklots,1972) }\end{array}$ \\
\hline
\end{tabular}

Description for the above table 


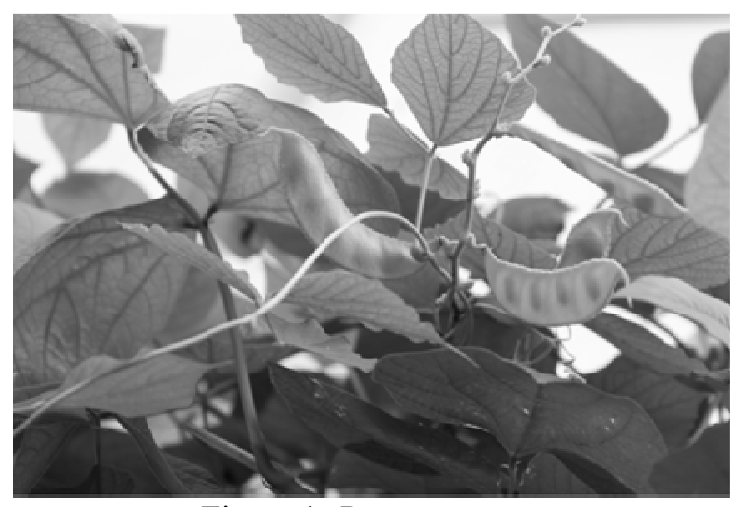

Figure 1. Pisum sativum

Description for the above figure

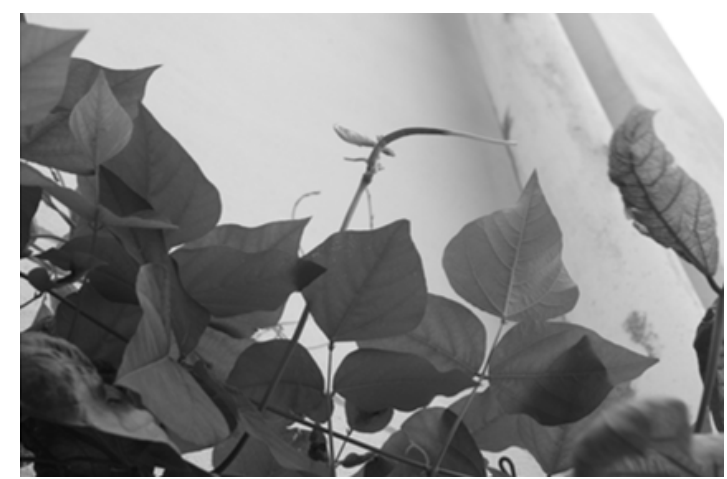

Figure 2. Vigna unguiculata subsp. sesquipedalis

Description for the above figure

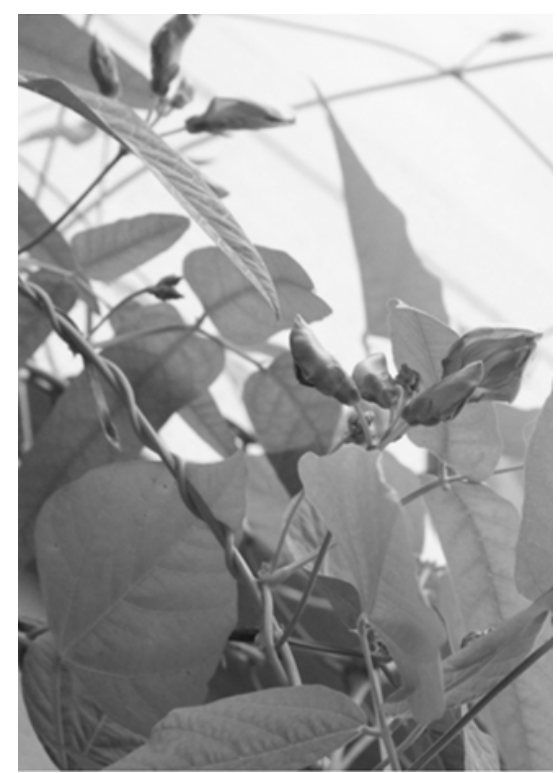

Figure 3. Psophocarpus tetragonolobus

Description for the above figure 


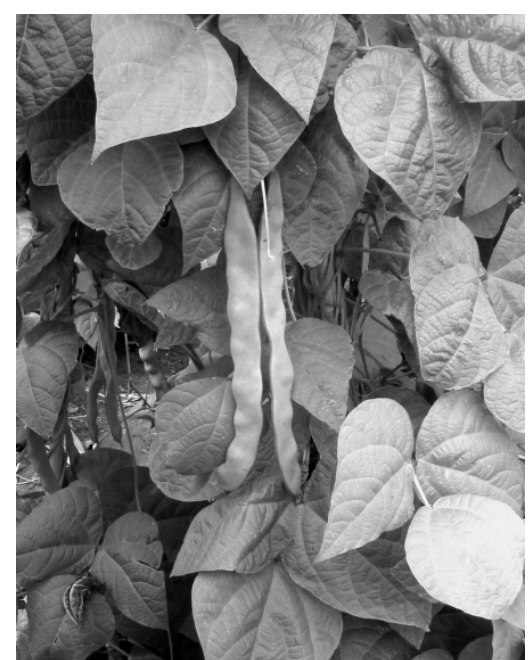

Figure 4. Phaseolus vulgaris

Source: http://en.wikipedia.org/wiki/Common_bean

Description for the above figure 